\title{
Implementing “Zakat”-Based Microfinance in Indonesia
}

\author{
Sudirman \\ Department of Family Law, Shari'a Faculty, Maulana Malik Ibrahim State Islamic University, Malang, \\ Indonesia
}

\begin{abstract}
This paper aims at describing the Bank of "Zakat" eL-Zawa as a potential zakat-based microfinance. eL-Zawa uses the donation from "muzakki" to be its capital and distributes that money to the poor. The contracts of fund distribution are mostly "qardh al-hasan" (free-interest loan) and "mudharabah" (profit-lost sharing). In "qardh al-hasan" program, eL-Zawa distributes the capital to the poor as interest-free loan. Meanwhile, in "mudharabah" version, it provides the capital for the successful members of "qardhul hasan" program to develop their business. Bank of "Zakat" eL-Zawa wants to implement professional system and still keeping its features: helping the poor and avoiding exploitation of the recipients.
\end{abstract}

Keywords: bank of zakat, microfinance, productive, profit-lost-sharing

\section{Introduction}

The possibility of "zakat" (almsgiving) to be the core source of funds for business still becomes an issue. "Zakat" as the third pillar of Islam is generally associated with the alleviation of poverty or the financial supports for poor people's daily needs (Nurzaman, 2010). However, the problem of management is still challenging (Sudewo, 2004). Many scholars have introduced various ways to reduce poverty by using "zakat" as a main tool (Permono, 2005, Sudirman, 2011, Ismail: 2013, Toriquddin, 2015). Recently, the ideas can be classified into three groups. First of all, some of them are of the opinion that "zakat" should be disbursed consumptively though direct distribution. The second group states that "zakat" can be distributed to the needy through consumptive programs as well as productive programs. The productive programs could be realized after the basic needs of the recipients have been fully met. The methods of the programs are by introducing or supporting the economic activities for the poor. The capital given is just kind of charity. They do not need to repay that money since "zakat" is considered as their own right. Next, the last category insists that the productive should be prioritized in delivering "zakat" because it can educate the poor to use the money effectively. Otherwise, they will become never-ended poor and weak since they just expect too much to receive "zakat" regularly. The most possible way to make them independent is by giving them soft loan. Therefore, they have to return the money in certain way. To implement this idea, establishment of bank of "zakat" or almsgiving-based microfinance is unavoidable.

This paper focuses on the third group. The institution explored in this paper is "eL-Zawa," as a case study of "zakat" institution which has program of productive "zakat" through microfinance. In addition, "eLZawa" is a university-based "zakat" institution which also focuses their programs on research.

\section{The Power of "Zakat": Revisited}

Indonesia, a country with the Muslims as majority, seeks to resolve the country's economic obstacles through potential charity. It seems to have some difficulty in managing this religion-based social fund while the total population of Indonesia is projected to reach 254.5 million people and almost $88 \%$ are Muslims (World Bank and BPS, 2015). The number of the very large Muslim population is an asset that can be utilized by the government to alleviate poverty and social inequality (Fuadi, 2014). Religious charity such as "zakat" is a promising tool to resolve the problems. The fact published by the National Zakat Agency (BAZNAS) and the Faculty of Economics and Management The Institute of Farm Bogor (IPB) in 2011 showed that the potential "zakat" in Indonesia reached to $3.4 \%$ of the total GDP, not less than 217 billion rupiahs every year It will become a strategic economic source when managed professionally.

The "zakat" institutions in Indonesia grow significantly. In 2014, the government of Indonesia has one of the National Zakat Agency, 34 Agencies at the Provincial level, 93 Zakat Board at the City level, and 398 Zakat Board at the District level. Meanwhile, the community has 22 Zakat Institutions that have earned the legality of law and 52 Zakat Institutions that have not got the legality of law both at provincial level and at district/ city level. The agency of the public for the implementation of that charity initiative has not included "zakat" management which is conducted by religious leaders such as foundations, religious scholars, preachers, and others. Thus, this enormous potency of "zakat" must become main concern of of various parties, such as policy makers, business people, and religious thinkers by introducing "zakat" management system covering collection, distribution and utilization of "zakat" funds, including "zakat"-tax relationship (Djuanda: 2006). 
One of scholar promoting the integration of collection, distribution and utilization of the "zakat" funds is Dakhoir (2014). In his paper, he asserts that the government as well as the community should pay more attention to "zakat" and initiate the productive "zakat" through banking system. For instance, BAZNAS as "zakat" collector institution perform "zakat" management in the form of money. Of course, it can lead to the uncertainty of the status of the institution since BAZNAS is not a kind of bank. Therefore, BAZNAS saves the funds of "zakat" in collaboration with the banking system, except in the management of "zakat" that can be directly distributed to the recipients. Likewise, other "zakat" collectors use the banking services as storage of their "zakat" funds. Thus, the "zakat" management institutions in the perspective of institutional certainty lead to the inaccuracies role when they do not work hand in hand with banks.

Furthermore, the management of "zakat" in the form of money should be built based on an integrated management of "zakat". The Formulation of integrated management of "zakat" normative framework is built based on the principles of social intermediation of "zakat" funds and the theory of legal certainty in the management of "zakat". The system of Legal order of "zakat" management integrates the principle of intermediation of "zakat" social fund and connects normative framework of the "zakat" management with related rules such as the Regulation of the Financial Services Authority which has the authority to supervise all financial institutions, especially financial institution such as banks associated with the Regulation of the Income Tax which sets "zakat" that can be a tax deduction, and associated with the Islamic Banking Regulation which has a dual function namely intermediation of business funds and the function of intermediary for social-religious fund such as "zakat" (Djuanda: 2006, Dakhoir: 2014, Marhaini: 2011).

In addition, the application of the bank of "zakat" in transforming the implementation of "zakat" can be a solution to the implementation of "zakat" in Indonesia. The concept of bank of "zakat" which prioritize the aspects of social enterprise and serves as a social institution for financial intermediation has realized an integrated system of "zakat" management. The meaning of an integrated management is positioning the implementation of collection of the "zakat" which is connected with either organization formed by the government or by society in managing "zakat" funds. Bank of "zakat" plays as the last treasure house or (bait al-mal) for the collection of "zakat" and becomes first property house in "zakat" funds.

The presence of the bank in the integrated management of "zakat" can build public confidence in the management of "zakat", because the banking system is built with the form with a system of integrated that integrates institution "zakat" products government, institution "zakat" products of society and monitoring system by Authority Financial Services (OJK), Supreme Audit Board (BPK), Report Center and Analysis Financial Transactions (PPATK), Corruption Eradication Commission (KPK) and income tax. Issues of control and supervision of "zakat" funds, including funds in an ideal perspective has been put the role of OJK in the future to supervise financial institutions including "zakat", hajj funds and other funds. The development of Islamic economic institutions such as bank of "zakat" will become the breakthrough of the most sophisticated accountable system which can be trusted in the management of "zakat" that ensure appropriate distribution of the property from the rich to the poor (Dakhoir: 2014).

The alternative solutions of effective and efficient "zakat" management is through integrated "zakat" management institutions. The institution of unified of integrated management of "zakat" which effective, efficient and accountable is the Islamic banking institutions through which has two main functions, namely as intermediary funding of the business profit and as a religious social intermediary institutions or charity fund institution such as "zakat" the specialty of the function of Islamic banking as intermediary of social fund (religious) such as "zakat" is the rational basis of the formation of the charity or "zakat" bank.

The bank of "zakat" is formed based on philosophical aspect that "zakat" as the religious economic instrument realizes the justice of "zakat" economy based on the principles of maqasid al-syaria (the goals of Islamic law) which ensure the maintenance of religion is "zakat", guaranteed circulation of "zakat" and the safety of the receiver of the alm. The bank of "zakat" is formed based on juridical aspect that the implementation of the alm should be integrated based on the regulation to ensure legal certainty in managing the alm. An integrated legal certainty puts the position of the basis of social finance intermediation and social enterprise in the regulation of sharia finance which is harmoniously related to the legislation of OJK, BPK, PPATK, KPK and Income tax. The bank of "zakat" is formed based on the sociological aspects that the implementation of the "zakat" system is built based on the principle of trust. The bank of "zakat" as a special bank managing "zakat" as a trust fund puts the trust fund as the trust of the givers that should be handed over and be used in accord with the Sharia that based on donation to those who have the rights to receive it (Dakhoir: 2014).

Another scholar which has the idea of integrating "zakat" into microfinance institution is Ibrahim (2014). She clearly states that "zakat" can be a mechanism for micro financing among the Muslim society, theso-called Zakat Micro Finance (ZMF). There are several non-profit instruments of securing funds, for example, "zakat," "sadaqah" (charity), and "waqaf" (endowment). These are all sources of funds for a microfinance 
mechanism and among the various forms of financial assistance that can be provided to the poor and needy Muslim to improve their socio-economic standard of living.

ZMF can be demanding as well as profitable ventures. She argues that exclusion of the poor from the financial system has become one of major factors contributing to their inability to participate in the development process. Microenterprises can employ surplus labour force productively. Therefore, the growth of microenterprises or small enterprises can improve the economy and be socially responsible by helping people who are in desperate need of financial assistance.

Furthermore, ZMF should avoid the practice of conventional microfinance. It should not pose two major obstacles to the Muslim poor. The first obstacle is in the form of collateral requirement which is usually beyond their capabilities. The second obstacle is the religious injunctions against interest (riba). Therefore, Islamic alternatives as ZMF promotes should be taken into account.

In some countries, micro finance assistance to the poor and needy has been proven to be successful in helping them to overcome their economic problems. In Iran for eample, a micro-financing scheme of qardul hasan (Qardul Hasan Micro Financing) has successfully helped the farmers and small businessmen, while in Bangladesh, the informal micro finance loan schemes (Informal Micro Credit) has helped especially small business owners and street hawkers in urban areas with financial difficulties (Raquib: 2011). However, financial resources used in Iran and Bangladesh in the above cases, did not come from "zakat" funds. The issue is, can "zakat" funds be used for micro credit loans? To support her argument, Ibrahim quotes Abu Zahrah and Yosuf who had allowed it to be. Abu Zahrah stated that if the borrower dies and his heirs cannot pay the debt, the debt can be paid using "zakat" funds. This means that Abu Zahrah allowing "zakat" funds to be used to provide interest-free loans to individuals in need. No worries about 'losing' "zakat" fund as a result of micro-credit as it is an interest free loan. This means that the fund (loan) will be paid back by the borrower. Should the borrower dies, the loan will be amortized using "zakat" funds from the provision of debtor (asnaf Gharimin).

In addition, the outstanding balance must be paid from the assets of the borrower. If inheritance is not enough, the unpaid debt would be (considered) bad debts. However, in Islam the debts due (fair debts), shall (be) solved using "zakat" funds. Yusof stressed that according to qiyas and the general purpose of Islamic teachings of "zakat", loan is allowed to be given to the needy from the part of the debtors (Gharimin) (Qardhawi: 1991). To him, "zakat" can be practically used to combat usury and removing all the usurious aspects (ribawi). In other words, loans in the form of qardul hassan from "zakat" fund will prevent them from involving in a loan that consists the element of riba. Another argument is that if the debt can be paid from "zakat" fund, then more importantly, borrowing could be done from the "zakat" fund by way of a good and clean from the elements of riba. This is a major qiyas (qiashul-aula). Thus, for the purpose of helping lowincome earners and those in needs, especially as business capital, "zakat" could be used to provide financial assistance to the needy and poor in the form of soft loans or interest-free loans.

The distribution of "zakat" is classified according to the usage of the fund, either in the form of consumption or production. Consumptive "zakat" distribution is given continuously for consumption purposes for a relatively long period of time. It covers food, shelter, transportation, medicine and schooling expenses. This type of assistance is mainly given to the non-productive group. On the other hand, productive "zakat" distribution is given for production purposes to the recipients that are productive. This assistance has long-term goals as to improve their quality and standard of living. "Zakat" assistance will be given to recipients to finance their economic projects for a long-term production and survival purposes. In a long term period, they are expected to become self-reliant and productive and able to pay zakat in return. The assistance given to them will be stopped once they have reached this level. Unlike the consumptive assistance which is given continuously, productive assistance is given for a short period of time only. The main goal is for a productive and effective use of resources to eradicate poverty.

\section{Bank of "Zakat" eL-Zawa: a Case Study}

eL-Zawa is a unique "zakat" institution based on campus. This institution lies at Universitas Islam Negeri Maulana Malik Ibrahim Malang (UIN Maliki Malang).The emergence of eL-Zawa started from Southeast Asia Zakat Seminar organized by the Faculty of Sharia UIN Maliki Malang in cooperation with Zakat Management Institute (IMZ) Jakarta and Zakat Research Institute, Universiti Teknologi Mara (UiTM) Melaka Malaysia on November 22, 2006. Since officially established in 2007, eL-Zawa has two main activities: the social empowerment and the research centre. Various development programs have been carried eL-Zawa, such as entrepreneurship training and community development. Meanwhile, to strengthen its position as a research centre" for "zakat" and "waqf," eL-Zawa has been carrying out various activities such as publishing books, trainings, and seminars.

Since 2007, eL-Zawa has organized funds from lecturers, officers, as well as students and distributes the money for helping other officers or students who have financial problems, through interest-free soft loan. This program has received a good response from people and now eL-Zawa has established microfinance, called 
Bank of "Zakat" eL-Zawa since 13 July 2013. One of features of this microfinance is that bank eL-Zawa does not take benefit from the customers. It lends the money to people without taking benefit, such as interest or riba. It just urge donation to customers. The reason why this institution does not make money from the loan program is because elzawa have several source for money, for instance, infaq and the benefit from their business.

\subsection{Qardhul Hasan}

\section{IV. eL-Zawa's Productive Programs}

As one of main programs, qardhul hasan can support internal as well as external mustahiqs at UIN Maulana Malik Ibrahim Malang to start their business. They can access interest-free loans to support their economic activities, such as small shop and home industry. From this loan, they can buy more raw materials without any burden to pay interest. It is a kind of efforts to combat interest-based finance which usually binds them with high rate of interest. Therefore, the recipients of qardhul hasan feel happy when they get this soft loan. Moreover, they may pay back this loan in quite long period, for example, 20 months or two years-length. When the instalments are completely paid, they may apply for the second period to get higher loan. In 2014 eLZawa has assisted 224 internal "mustahiqs" who enjoy this "qardhul hasan" program with total funds around 632 millions rupiahs.

eL-Zawa focuses on managing "zakat" funds productively for public welfare. It has expanded its activities to help people outside campus. It has a Qardhul hasan program for people who have economic activities. eL-Zawa has developed this program through a series of research. One of research reports reveals that people should be selected and supervised gradually. It has to select their quality by interviewing them and observation. Besides, eL-Zawa involves the key persons that have powerful charisma/charismatic figures. It also conducts regular supervision, such as in its pilot project at Kucur. In 2014, it has 123 economic units. These customers spread over nine districts in Malang: Kedungkandang, Merjosari, breadfruit, Tumpang, Gondang Legi, Lowok Waru, Donomulyo, Karangploso, Sumberpucung and Kucur. In 2014 there were 45 new customers with total of 156 millions rupiahs. In 2015, eL-Zawa tries to support more people for their capital. If the member of Qadhul hasan are successful in their bussiness, el-Zawa will give them another program, called, Mudharabah.

\subsection{Mudharabah}

Mudharabah is an advanced program of Qardhul Hasan for customers who can be categorized as a potential candidate of new muzakki. Profit sharing ratio introduced by eL-Zawa is just no more then $10 \%$ of the profit. The instalment scheme can be made during a year. This mechanism will ease business owners to develop their business. In 2014, there were 13 mudarabah new customers with total financing of 105 millions rupiahs.

\subsection{Soft-skill Training}

Another program is soft skill-training. The high number of educated unemployment in Indonesia encourage higher education institutions to provide additional soft skills for students. Thus, in addition to the core competencies of the students, they also have soft skill to develop their potential after graduation. In addition, the skill up-dating is also implemented for community members to raise their ability to access various economic activities.

\subsection{Motorcycle loan scheme}

Finally, eL-Zawa has a unique program: qardhul hasan for motorcycle. It seems to be consumptive but it can increase the productivity of employees. This program aims at supporting mustahiq of the university employee, such as part-timer workers, to have new motorcycle to support their mobility. Some of them have improper motorcycle and they still use public transport. eL-Zawa launched motorcycle qardhul hasan for mustahiq at UIN Maliki, hoping to increase the mobility and avoid them from interest when they buy motorcycles from dealer though credit scheme. The mechanism is that eL-Zawa buy the intended motorcycle and the mustahiq pay the motorcycle price without addition fee. It has a slogan "buy motorcycle by credit, but install the price like by cash". So, the price will be $60 \%$ lower than that from dealer. Thus, the purpose of the program is clearly to assist and support poor people to have a better life.

From the above description, in can inferred that eL-Zawa has played significant role for enhancing the level of economic life of the recipients. In the beginning of its activities in 2007, eL-Zawa just collected funds no more then 250 thousands rupiahs. But now it has develop the program via microfinance to organize fresh money more than 1.6 billion rupiahs in 2014. eL-Zawa becomes one of successful "zakat" based microfinance with its characteristics (eL-Zawa Annual Report: 2014).

One of key points to keep eL-Zawa microfinance surviving is the support of the rector. The rector has issued a decree that all workers at UIN Maulana Malik Ibrahim should pay their "zakat" to eL-Zawa. They have to allocate from their salary around $2.5 \%$ for "zakat". This massive movement has been very successful to 
collect money for about 50 millions rupiahs each month. The rector has urged vice rector, dean, vice dean, and some head of units to pay their "zakat" through eL-Zawa. The funds then might be placed as the capital of bank of "zakat". It is not from third party capitals that usually require high interest. Therefore, eL-Zawa microfinance can continue to exist independently. Bank of "zakat" has played a significant role in helping mustahiq. It can be a role model for university, especially, Islamic university to work harder to help student, employee, and people outside campus to live more meaningful. If all campus do like this, and have "zakat"-based microfinance, it will be a good way to reduce poverty and make the recipients more financially independent.

\section{Conclusion}

From the discussion above, it can be inferred that "zakat" has very important role to reduce poverty, for instance, through bank of "zakat" or microfinance. eL-Zawa has successfully implemented this kind of microfinance. Hopefully, this idea can be adopted by other "zakat" institute to disburse "zakat" productively. Thus, the cooperation between various elements, including government, university, and "zakat" institutions, is highly respected to make "zakat" as a tool of social change may come into reality.

\section{References}

[1]. Nurzaman, Mohamad Soleh, Zakat and Human Development: An Empirical Analysis on Poverty Alleviation in Jakarta, Indonesia, 8th International Conference on Islamic Economics and Finance.

[2]. Sudewo, Eri, 2004, Manajemen Zakat, Tinggalkan 15 Tradisi, Tetapkan 4 Prinsip Dasar, Jakarta: Institut Manajemen Zakat.

[3]. Permono, Sjechul Hadi, 2005, Formula Zakat Menuju Kesejahteraan Sosial, Surabaya: Aulia.

[4]. Sudirman and Sri Eko Ayu Indrawati, 2011, Implementasi Total Quality Management dalam Pengelolaan Zakat di Kota Malang, De Jure Journal, Vol. 3, No. 2.

[5]. Ismail, Abdul Ghafar (el.al), 2013, Debate on Policy Issues in the Field of Zakat on Islamic Bank Business, IRTI Policy Paper.

[6]. Thoriquddin, Moh, 2015, Pengelolaan Zakat Produktif Perspektif Maqasid al-Syari'ah Ibnu Asyur, Malang: UIN Malang Press, $140-144$.

[7]. World bank, www.worldbank.org, accessed on 8 June 2016.

[8]. BPS, www.bps.go.id, accessed on 8 June 2016.

[9]. Fuadi, "The Authority of Aceh Government in Managing Zakat as a Source of Local Revenue," IOSR Journal of Economics and Finance (IOSR-JEF), e-ISSN: 2321-5933, p-ISSN: 2321-5925.Volume 5, Issue 2. (Sep.-Oct. 2014), 18-27

[10]. Djuanda, Gustian, Pelaporan Zakat Pengurang Pajak Penghasilan, Jakarta: RajaGrafindo, 2006.

[11]. Dakhoir, Ahmad (et.al), 2014, The Bank of Alm (Zakat): Ideas, Structure, and the Implementation of the Integrated Alm Management, Journal of Law, Policy and Globalization ISSN 2224-3240 (Paper) ISSN 2224-3259, Vol.25

[12]. Marhaini, Wan, Wan Ahmad and Shamsiah Mohamad, 2011, Classical Jurists' View on the Allocation of Zakat: Is Zakat Investment Allowed? Journal of Islamic Economics, Banking and Finance, Vol. 7 No. 2, Apr-Jun 2011.

[13]. Raquib, Abdur, Islamic Banking \& Zakat- An Alternative Approach to Poverty Reduction in Bangladesh, Journal of Islamic Economics, Banking, and Finance, Vol 7 No. 2 Apr-June 2011, 11-26

[14]. Qardhawi, Yusuf, 1991, Fiqh al-Zakat, Beyrut: Muassasah al-Risalah.

[15]. Ibrahim, Patmawati, and Ruziah Ghazali, Zakah As An Islamic Micro-Financing Mechanism To Productive Zakah Recipients, Asian Economic and Financial Review, 2014, 4(1): 117-125

[16]. Hafidhuddin, Didin (et.al), 2008, The Power of Zakat: Studi Perbandingan Pengelolaan Zakat Asia Tenggara, Malang: UINMalang Press.

[17]. eL-Zawa, www.elzawa.uin-malang.ac.id/868/ accessed on 10 June 2016 